\title{
PERSEPSI MASYARAKAT TERHADAP PENGOBATAN TRADISIONAL BERDASARKAN PENDIDIKAN DI KABUPATEN PURWAKARTA
}

\author{
Jenta Puspariki', Suharti² \\ 1,2,3Sekolah Tinggi Ilmu Kesehatan Holistik \\ Korespondensi: Jl. Veteran No. 272 Ciseureuh Purwakarta, Email: jenta@stikesholistic.ac.id \& \\ suharti@stikesholistic.ac.id
}

\begin{abstract}
ABSTRAK
Latar Belakang: Penggunaan obat kimia dalam waktu lama dapat menimbulkan penyakit baru karena banyak organ tubuh rusak akibat obat kimia. Sadar akan bahaya tersebut, masyarakat mulai mengurangi penggunaan obat kimia dan beralih ke obat-obat tradisional. Meskipun penggunaan obat tradisional sudah banyak namun data pendidikan pengguna obat tradisional masih sedikit. Informasi latar belakang pendidikan diteliti karena pendidikan yang dimiliki dapat mempengaruhi persepsi salah satunya persepsi terhadap obat tradisional.

Tujuan: Mengeksplorasi persepsi masyarakat tentang pengobatan tradisional berdasarkan pendidikan.

Metode: Penelitian eksplanatif asosiatif yang bersifat kualitatif. Subjek penelitiannya masyarakat Kabupaten Purwakarta sebanyak 137 orang. Pemilihan dan pengambilan sampel menggunakan metode conditional sampling, yang dianalisis menurut skala Ridwan (2003). Pengambilan data menggunakan kuesioner.

Hasil: Kelompok tidak pernah kuliah (TPK) memiliki persepsi dan animo sangat setuju dan setuju terhadap obat tradisional sebesar 78,7\%, S1 62,7\% dan pada S2/S3 66\%. Kelompok TPK setuju dan sangat setuju pengobatan tradisional memiliki potensi untuk dikembangkan dengan persentase $81,9 \%$, S1 70,3\% dan S2/S3 76,7\%. Kelompok TPK setuju dan sangat setuju pengobatan tradisional cukup memberi bukti menyembuhkan penyakit dengan persentase $67,4 \%$, S1 51,8\% dan S2/S3 50\%. Kelompok TPK setuju dan sangat setuju fasilitas pengobatan tradisional masih seadanya sebesar 80,4\%, S1 yang setuju sebesar 50,6\% dan S2/S3 yang setuju sebesar $50 \%$.
\end{abstract}

Simpulan: Persepsi dan animo terhadap obat tradisional dan potensi pengembangan obat tradisional menunjukan persentase yang besar pada kelompok TPK, selanjutnya S2/S3 kemudian S1. Untuk pengobatan tradisional cukup memberi bukti penyembuhan penyakit dan fasilitas praktik pengobatan tradisional menunjukan persentase yang besar pada kelompok TPK, selanjutnya S1 dan yang terakhir S2/S3.

Kata kunci: persepsi masyarakat, pengobatan tradisional, tingkat pendidikan responden

\begin{abstract}
Background: The use of chemical drugs for long periods can lead to new disease for many body organs damaged by chemical drugs. Aware of the danger, people are starting to reduce the use of chemical drugs and turn to traditional medicines. Although the use of traditional medicine has a lot of data but user education is still a bit of traditional medicine. Background information studied education because education can influence the perception held one perception to traditional medicine.
\end{abstract}

Objective: To explore community perceptions of traditional medicine based education.

Method: The study is a qualitative explanatory associative. His research interests Purwakarta Regency society as much as 137 people. Selection and sampling using conditional sampling method, which is analyzed by the scale Ridwan (2009). Retrieving data using questionnaires.

Results: The group never attended (TPK) perception and interest strongly agree and agree to traditional medicine by $78.7 \%, 62.7 \%$ and at S1 S2 / S3 66\%. TPK groups agree and strongly agree traditional medicine has the potential to be developed with a percentage of $81.9 \%, 70.3 \%$ S1 and S2 / S3 76.7\%. TPK groups agree and strongly agree folk medicine cure enough to give evidence to the percentage of $67.4 \%, 51.8 \%$ S1 and S2 / S3 50\%. TPK groups agree and strongly agree 
traditional treatment facilities are still modest at 80.4\%, S1 agreed amounted to 50.6\% and S2 / S3 are agreed by $50 \%$.

Conclusion: For the perception and interest towards traditional medicine and traditional medicine shows potential for the development of a large percentage of the group TPK, then S2 / S3 then S1. Traditional treatment sufficient to provide evidence of healing and traditional medicine practices facilities showed a large percentage in the group of TPK, the next and last S1 S2 / S3.

Key words: public perception, traditional medicine, education level of respondents

\section{PENDAHULUAN}

Konsumsi obat kimia oleh masyarakat dilakukan karena reaksinya begitu cepat dalam mengatasi suatu penyakit, namun demikian reaksi tersebut sebenarnya tidak mengatasi penyebab penyakit tersebut melainkan hanya menekan gejala yang timbul. Penggunaan obat kimia dalam jangka waktu yang lama juga dapat menimbulkan penyakit baru karena banyak organ-organ tubuh yang rusak akibat obat kimia tersebut.

Sadar akan bahaya tersebut, masyarakat mulai mengurangi penggunaan obat kimia dan beralih ke obat-obat tradisional. Penggunaan obat tradisional yang semakin berkembang dapat terlihat dari maraknya produk-produk berbahan herbal yang beredar di pasaran, tumbuhnya fasilitas kesehatan tradisional, maraknya iklan layanan pengobatan tradisional di televisi.

Obat tradisional menurut Departemen Kesehatan Republik Indonesia merupakan produk yang terbuat dari bahan alam yang jenis dan sifat kandungannya sangat beragam dan secara turun temurun telah digunakan untuk pengobatan berdasarkan pengalaman1. Penggunaan obat tradisional secara umum dinilai lebih aman dari pada penggunaan obat modern karena obat tradisional memiliki efek samping yang relatif lebih sedikit dari pada obat modern2.

Meskipun penggunaan obat tradisional di kalangan masyarakat sudah banyak namun data tentang latar persepsi pengguna obat tradisional berdasarkan pendidikan masih sedikit. Informasi tentang latar belakang pendidikan dipilih karena pendidikan atau informasi yang dimiliki seseorang dapat mempengaruhi persepsi salah satunya persepsi terhadap obat tradisional yang nantinya akan mempengaruhi perilaku penggunaan obat tradisional. Oleh karena itu penelitian seperti survei perlu dilakukan dengan harapan dapat menjadi gambaran bagi masyarakat dan pemerintah tentang bagaimana persepsi masyarakat dengan latar belakang pendidikan yang berbeda terhadap penggunaan obat tradisional. Selanjutnya, informasi tersebut dapat menjadi bahan pertimbangan untuk pemerintah dalam merencanakan dan melaksanakan program terkait obat tradisional sehingga dapat memaksimalkan hasil terapi, menyediakan perawatan medis yang berkualitas kepada masyarakat, membangun masyarakat yang sehat sejahtera.

\section{METODE PENELITIAN}

Penelitian ini merupakan penelitian eksplanatif asosiatif yang bersifat kualitatif pada masyarakat yang terhubung dengan pelayanan kesehatan. Subjek penelitian adalah masyarakat Kabupaten Purwakarta Propinsi Jawa Barat yang berjumlah 137 orang, dengan keragaman karakteristik responden tingkat pendidikan (tidak pernah kuliah (TPK); sarjana-S1; dan paskasarjana-S2/S3) dan pilihan persepsi responden yang mencakup tidak setuju, kurang setuju, netral, setuju dan sangat setuju sebagai varibel tidak tetap. Data penelitian diperoleh melalui kuesioner yang diisi oleh responden (subjek), melalui beberapa pertemuan kelompok masyarakat yang mewakili perkotaan (city), transisi (urban), dan pedesaan (rural). Kuesioner penelitian yang digunakan berisi pilihan persepsi pernyataan kinerja dari lembaga di bidang kesehatan. Jumlah atau persentase persepsi responden kemudian diukur menggunakan skala Ridwan ${ }^{3}$.

\section{HASIL PENELITIAN}


Berikut ini merupakan gambar grafik hasil penelitian untuk mengetahui respon masyarakat terhadap pengobatan tradisional.

\section{Grafik 1}

\section{Persentase Persepsi Pengetahuan dan Animo terhadap Pengobatan} Tradisional

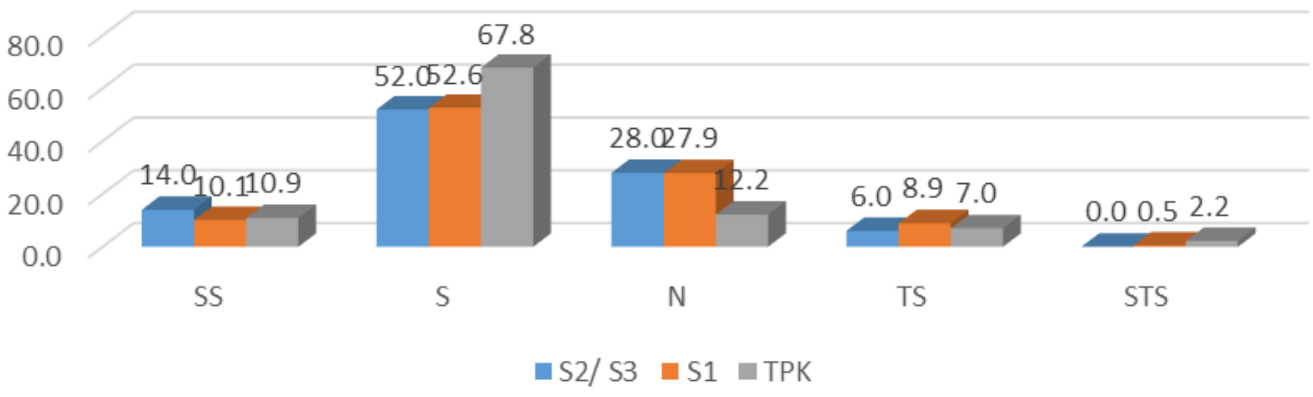

\section{Keterangan:}

Persepsi: SS (Sangat Setuju); S (Setuju); N (Netral); TS (Tidak Setuju); STS (Sangat Tidak Setuju)

Scoring: Sangat lemah (0-20); Lemah (21-40); Cukup (41-60); Kuat (61-80); Sangat kuat (81-100)

Sumber Riduan 2003

Grafik 1 merupakan grafik yang menggambarkan data tentang persepsi pengetahuan dan animo masyarakat terhadap pengobatan tradisional berdasarkan pendidikan. Grafik tersebut menunjukan bahwa kelompok tidak pernah kuliah (TPK) memiliki persepsi dan animo yang kuat (sangat setuju dan setuju) terhadap obat tradisional sebesar 78,7\%, sedangkan pada kelompok S1 yang sebanyak $62,7 \%$ dan pada kelompok S2/S3 yang setuju sebanyak $66 \%$.

\section{Grafik 2 \\ Persentase Persepsi Potensi Pengembangan terhadap Pengobatan Tradisional}

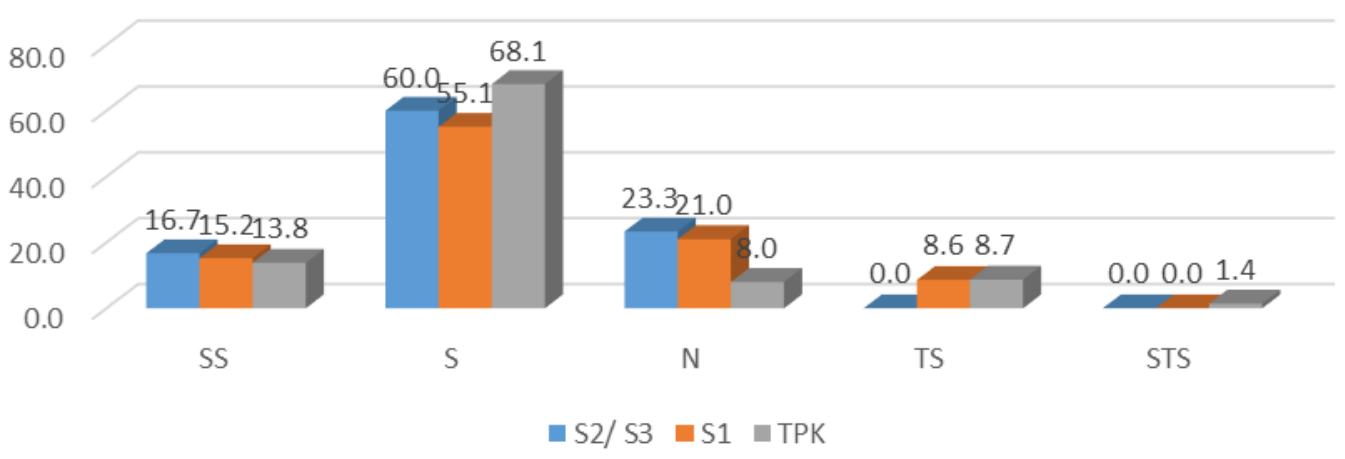

\section{Keterangan:}

Persepsi: SS (Sangat Setuju); S (Setuju); N (Netral); TS (Tidak Setuju); STS (Sangat Tidak Setuju) Scoring: Sangat lemah (0-20); Lemah (21-40); Cukup (41-60); Kuat (61-80); Sangat kuat (81-100) Sumber Riduan 2003

Grafik 2 merupakan grafik penelitian yang menjaring data tentang potensi pengembangan obat tradisional. Hasil pada grafik ini menunjukkan bahwa kelompok tidak pernah kuliah (TPK) setuju dan sangat setuju bahwa pengobatan tradisional memiliki potensi yang kuat untuk dikembangkan dengan persentase 81,9\% sedangkan pada kelompok S1 yang setuju 
sebesar $70,3 \%$ dan kelompok S2/S3 yang setuju sebesar 76,7\%.

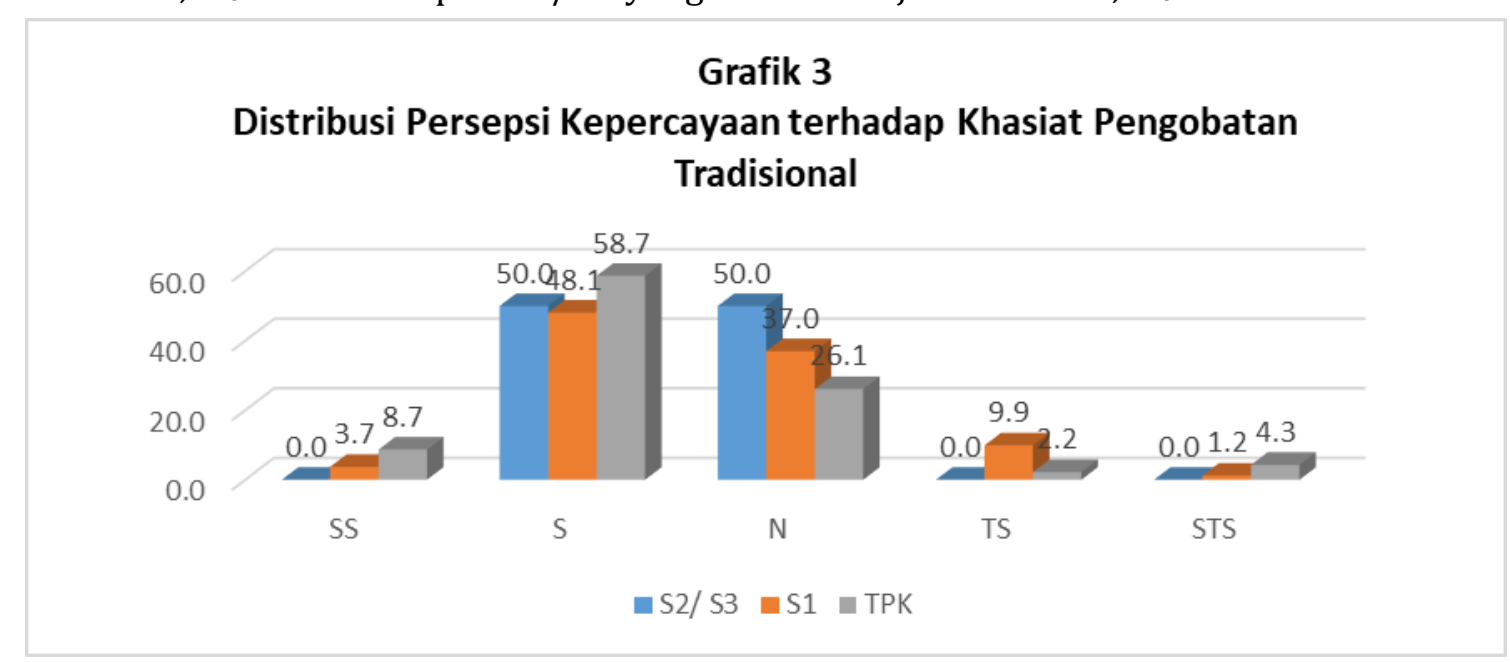

\section{Keterangan:}

Persepsi: SS (Sangat Setuju); S (Setuju); N (Netral); TS (Tidak Setuju); STS (Sangat Tidak Setuju) Scoring: Sangat lemah (0-20); Lemah (21-40); Cukup (41-60); Kuat (61-80); Sangat kuat (81-100) Sumber Riduan 2019

Grafik 3 merupakan grafik yang menjaring data tentang persepsi kepercayaan terhadap khasiat pengobatan tradisional. Hasil pada grafik menunjukkan bahwa kelompok tidak pernah kuliah (TPK) setuju dan sangat setuju bahwa pengobatan tradisional cukup memberi bukti menyembuhkan penyakit dengan persentase $67,4 \%$ sedangkan pada kelompok S1 yang setuju sebesar 51,8\% dan kelompok S2/S3 yang setuju sebesar $50 \%$.

\section{Grafik 4}

Distribusi Persepsi Kepercayaan terhadap Mutu (Standarisasi)

Pengobatan Tradisional

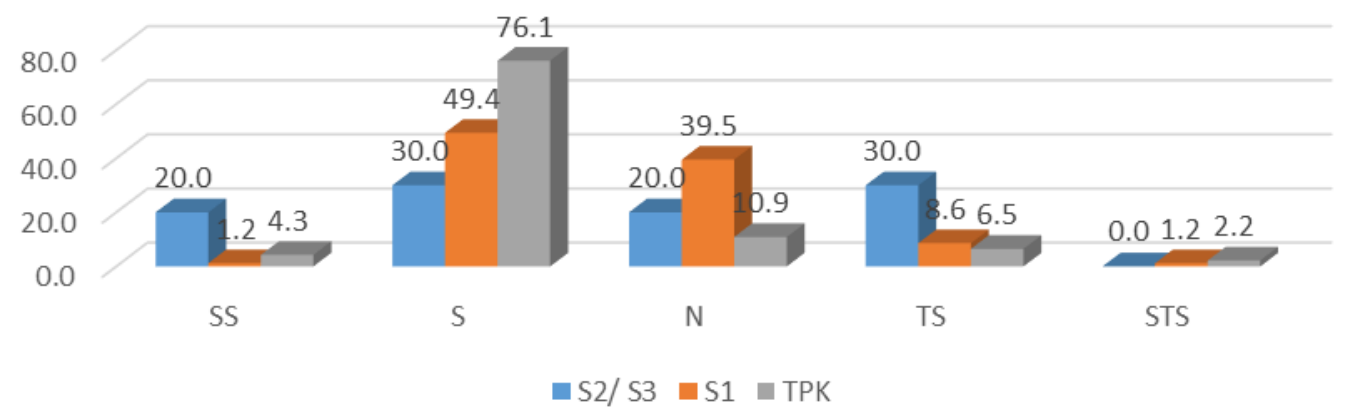

\section{Keterangan:}

Persepsi: SS (Sangat Setuju); S (Setuju); N (Netral); TS (Tidak Setuju); STS (Sangat Tidak Setuju) Scoring: Sangat lemah (0-20); Lemah (21-40); Cukup (41-60); Kuat (61-80); Sangat kuat (81-100) Sumber Riduan 2019

Grafik 4 merupakan grafik yang menjaring data tentang persepsi kepercayaan terhadap mutu (standarisasi). Hasil pada grafik ini menunjukkan kelompok tidak pernah kuliah (TPK) setuju dan sangat setuju bahwa fasilitas praktik dari upaya pengobatan tradisional masih seadanya sebesar 80,4\%, sedangkan kelompok S1 yang setuju sebesar 50,6\% dan kelompok S2/S3 yang setuju sebesar $50 \%$.

\section{PEMBAHASAN}


Hasil penelitian menunjukkan bahwa terdapat perbedaan hasil untuk persepsi dan animo terhadap obat tradisional, potensi pengembangan obat tradisional, pengobatan tradisional cukup memberi bukti penyembuhan penyakit, dan fasilitas praktik pengobatan tradisional pada kelompok tidak pernah kuliah (TPK), S1, dan S2/S3. Hasil untuk persepsi dan animo terhadap obat tradisional dan potensi pengembangan obat tradisional menunjukan persentase yang besar diberikan oleh kelompok tidak pernah kuliah (TPK), selanjutnya oleh kelompok S2/S3 kemudian kelompok S1. Adapun hasil untuk pengobatan tradisional cukup memberi bukti penyembuhan penyakit dan fasilitas praktik pengobatan tradisional menunjukan persentase yang besar pada kelompok tidak pernah kuliah (TPK), selanjutnya oleh kelompok S1 dan yang terakhir kelompok S1.

Bila melihat latar belakang pendidikan pada ketiga kelompok tersebut, pendidikan memang sangat berpengaruh terhadap cara berpikir kelompok masyarakat tersebut terhadap obat tradisional. Teori mengatakan bahwa pendidikan adalah suatu kegiatan atau proses pembelajaran untuk mengembangkan atau meningkatkan kemampuan tertentu sehingga sasaran pendidikan itu dapat berdiri sendiri. Tingkat pendidikan turut pula menentukan mudah tidaknya seseorang dalam menyerap dan memahami pengetahuan yang mereka peroleh, pada umumnya semakin tinggi pendidikan seseorang semakin baik pula pengetahuanya ${ }^{4}$.

Kelompok masyarakat tidak pernah kuliah (TPK) ternyata menunjukan hasil postif yang lebih besar pada pengobatan tradisional dibandingkan dengan kelompok S1, S2/S3 disebabkan karena kurangnya informasi dan pemahaman terhadap obat kimia modern pada kelompok tidak pernah kuliah. Menurut Imadha $^{5}$ kelompok masyarakat yang tidak pernah kuliah (TPK) memiliki karakteristik lambat dalam memahami sebuah masalah, cara berpikirnya tidak berdasarkan fakta, tidak menyeluruh, tidak kritis, tidak logis, tidak mampu berpikir analitis, tidak memahami substansi, tidak objektif, tidak punya referensi, tidak rasional, dan tidak signifikan karena kurangnya proses belajar. Dengan karakteristik seperti itu maka kelompok tidak pernah kuliah (TPK) akan memberikan respon terhadap obat tradisional lebih baik karena sudah mengenal banyak tentang obat tradisional sejak kecil dan diwariskan turun temurun. Hal ini sejalan dengan penelitian Jabar 6 yang menyatakan bahwa pengetahuan tentang obat modern yang rendah membuat responden lebih memilih menggunakan obat tradisional yang memang secara langsung mereka warisi dan gunakan secara turun-temurun pada lingkungan keluarganya.

Persepsi kelompok S1 dan kelompok S2/S3 cenderung lebih rendah terhadap obat tradisonal daripada kelompok tidak pernah kuliah (TPK) dikarenakan kelompok ini memiliki pendidikan dan informasi yang lebih banyak akan obat-obat modern. Bila dilihat lebih seksama maka hasil pada kelompok S2/S3 relatif lebih tinggi daripada kelompok S1. Penyebab dari perbedaan ini menurut Gustian 7 dapat terjadi karena perbedaan cara berpikir yang disebabkan pengalaman pendidikan. Gustian menyatakan, pada pendidikan sarjana terdapat kegiatan pembuatan skripsi yang bertujuan untuk membentuk pola berpikir sistematis dan metodologis sehingga tidak "ngawur" dan melompat-lompat. Pendidikan sarjana akan membentuk pemahaman tentang dunia yang lebih tepat, belajar bahan dan materi yang lebih sukar, mampu menerapkan ilmu untuk persoalanpersoalan yang generik. Adapun pendidikan paskasarjana yaitu S2/S3, kegiatannya lebih fokus memikirkan hal-hal yang sifatnya strategis dan akibatnya ke depan. Kegiatan pendidikan paskasarjana meliputi merenung, memahami, meneliti, dan menghasilkan suatu inovasi terhadap sebuah objek. Dari penjelasan tersebut dapat dimaknai bahwa pengetahuan kelompok S1 yang bersifat taktis memberikan efek skeptis terhadap pengobatan tradisional sebaliknya pada 
S2/S3 dengan pengetahuannya yang lebih mendalam dan sikap bijak berdampak pada dukungan yang kuat terhadap pengobatan tradisional. Hal ini sejalan dengan pernyataan bahwa profesi kesehatan/dokter masih enggan untuk meresepkan atau menggunakan cara pengobatan tradisional karena bukti ilmiah mengenai khasiat dan keamanan obat tradisional pada manusia masih kurang8.

Data dari hasil penelitian ini diharapkan dapat menjadi masukan bagi pemerintah setempat untuk melakukan program pendampingan penggunaan obat tradisional bagi kelompok tidak pernah kuliah (TPK) dan mengembangkan pengobatan tradisional yang aman dan terstandar sehingga dipercaya oleh seluruh kalangan masyarakat dalam meningkatkan kesehatan masyarakat.

\section{SIMPULAN}

Untuk persepsi dan animo terhadap obat tradisional dan potensi pengembangan obat tradisional menunjukan persentase yang besar pada kelompok tidak pernah kuliah (TPK), selanjutnya S2/S3 kemudian S1. Adapun untuk pengobatan tradisional cukup memberi bukti penyembuhan penyakit dan fasilitas praktik pengobatan tradisional menunjukan persentase yang besar pada kelompok TPK, selanjutnya S1 dan yang terakhir S2/S3.

\section{DAFTAR PUSTAKA}

1. Depkes. Keputusan Menteri Kesehatan 381/Menkes/SK/III/2007. Kebijakan Obat Tradisional. Departemen Kesehatan Republik Indonesia. 2007.
2. Pramono S, Kontribusi bahan obat alam dalam mengatasi krisis bahan obat di Indonesia. Jurnal Bahan Alam Indonesia, 2002, 1(1); 18-20.

3. Riduan. (2003). Dasar-dasar Statistika. Bandung: Alfabeta

4. Oktarisa Khairiyah Ar-Rasily 1, Puspita Kusuma Dewi. (2016). Faktor -Faktor Yang Mempengaruhi Tingkat Pengetahuan Orang Tua Mengenai Kelainan Genetik Penyebab Disabilitas Intelektual Di Kota Semarang. Jurnal Kedokteran Diponegoro Volume 5, Nomor 4, Oktober 2016. ISSN Online : 2540-8844

5. Jabbar, A., Musdalipah, Nurwati, A. Studi Pengetahuan, Sikap Dan Tindakan Terhadap Penggunaan Obat Tradisional Bagi Masyarakat Di Desa Sabi-Sabila Kecamatan Mowewe Kabupaten Kolaka Timur, Pharmauho Volume 3, No. 1, Hal. 19-22, Majalah Farmasi, Sains, Dan Kesehatan, 2016, ISSN 2442-9791

6. Gustian, D. (2015). Perbedaan Pola Pikir Sarjana Magister. [Online] Http://Catatan-

Dudihgustian.Blogspot.Com/2015/03/P erbedaan-Pola-Pikir-SarjanaMagister.Html

7. Imadha, H. ( 2011). Filsafat Beda Cara Berpikir Sarjana Dan Bukan Sarjana. [Online] Https://Ffugm.Wordpress.Com/2011/0 3/11/Filsafat-Beda-Cara-BerpikirSarjana-Dan-Bukan-Sarjana/

8. Dewoto H.R. (2007), Pengembangan Obat Trasional Indonesia Menjadi Fitofarmaka, Majalah Kedokteran Indonesia, Volume 57, Nomor 7, Jakarta. 